УДК $811.111 ’ 38$

DOI https://doi.org/10.26661/2414-1135-2021-83-36

\title{
РІЗДВЯНЕ ЗВЕРНЕННЯ БРИТАНСЬКОЇ КОРОЛЕВИ У 2020 РОЦІ В НОВИННИХ СТАТТЯХ: МОДЕЛІ ТРАНСФОРМАЦЇ̈
}

\author{
Талавіра Н. М. \\ кандидат філологічних наук, дочент, \\ доцент кафедри германської філології \\ та методики викладання іноземних мов \\ Ніжинський державний університет імені Миколи Гоголя \\ вул. Графська, 2, Ніжин, Украӥна \\ orcid.org/0000-0002-5600-5893 \\ nataliia.talavira@ndu.edu.ua
}

\begin{abstract}
Ключові слова: риторика, трансформація, публічний виступ, медійний текст, різдвяне звернення.
\end{abstract}

\begin{abstract}
Міжжанрова трансформація різдвяного звернення британської королеви імплікує перекодування його змісту засобами медійного жанру, за якого відбувається модифікація як композиції, так і мовних одиниць. Розвідка пропонує моделі трансформації промови Слизавети II в трьох онлайн виданнях: британському, американському та канадському. 3 точки зору диспозиції різдвяне звернення королеви у 2020 році висвітлює боротьбу iii народу з пандемією коронавірусу й представлено вісьмома темами, розміщення яких підпорядковане авторському наміру впливу на масову аудиторію. При цьому промова королеви містить три ключові ідеї: світло, що приносить надію; іiї захоплення вчинками людей у скрутний час; вдячність як працівникам медичної сфери, так і волонтерам. Репрезентація промови королеви в британському виданні зорієнтована на позиціонування монарха як турботливої та вдячної людини. При цьому в сильні позиції тексту винесено ідею підтримки та слова розради й заспокоєння, а порядок подачі тем в основному блоці відображає необхідність підбадьорити людей під час пандемії. Вербалізація змісту промови в американському виданні акцентує ідею підтримки, схвалення монархом роботи медпрацівників i зворушення незламним духом пересічних громадян, тоді як в основному блоці статті відображено ієрархію тем згідно з роллю релігійного свята та звичними для віруючих практиками. Канадське видання виносить у заголовок ідею надії та вказує на зближення людей, основний блок тексту відзначається орієнтацією на вклад пересічних людей у боротьбу з вірусом, цитує слова підтримки й вдячності. Усі три видання надають слова розради тим, хто пережив втрату рідних чи друзів, прямо цитуючи королеву для підсилення важливості й об'єктивності новини; відображають вдячність медпрацівникам і надають незмінною заключну частину промови, присвячену ролі Різдва в житті вірян, що зумовлено призначенням щорічного звернення Слизавети II. Відмінності в подачі змісту щорічного звернення королеви зумовлені спрямованістю кожного видання на власного адресата 3 його потребами й фоновими знаннями.
\end{abstract}




\title{
REPRESENTING QUEEN ELIZABETH II'S CHRISTMAS ADDRESS 2020 IN NEWS TEXTS: TRANSFORMATION MODELS
}

\author{
Talavira N. M. \\ Candidate of Philological Sciences, \\ Associate Professor at the Chair of Germanic Languages and Methods \\ of Teaching Foreign Languages \\ Nizhyn Mykola Gogol State University \\ Grafska str., 2, Nizhyn, Ukraine \\ orcid.org/0000-0002-5600-5893 \\ nataliia.talavira@ndu.edu.ua
}

Key words: rhetoric, transformation, public speech, media text, Christmas address.

\begin{abstract}
The intergenre transformation of the British queen's Christmas address implies the recoding of its content by means of the mediagenre, with both the composition and the linguistic units being modified. The survey offers transformation models of Elizabeth II's speech in three online publications: British, American and Canadian. In terms of disposition, the Queen's Christmas address in 2020 highlights the struggle of her people against the coronavirus pandemic and is represented by eight themes, the arrangement of which is subject to the author's intention to influence mass audience. In this case, the Queen's speech contains three key ideas: the light that brings hope; her fascination with the actions of people in challenging times; gratitude to both frontline workers and volunteers. The representation of the sovereign's speech in the British issue is focused on positioning the monarch as a caring and thankful person. The idea of support and words of consolation and reassurance are represented in the strong positions of the text, and the placement of the topics in the main block reflects the need to encourage people during the pandemic. Verbalization of the speech content in the American issue emphasizes the idea of support, monarch's approval of frontline workers and the indomitable spirit of ordinary citizens, while the main block of the article reflects the hierarchy of topics as to the role of religious holiday and its practices. The Canadian publication puts the idea of hope in the headline and points to the rapprochement of people, the main block of the text focuses on the contribution of ordinary people to the fight against the virus, quotes words of support and gratitude. All three news texts offer words of consolation to those who have lost those dear to them, directly quoting the Queen to enhance the objectivity of the news; reflect gratitude to the medical staff and provide the final part of the speech on the role of Christmas for believers. Differences in the presentation of the speech content are due to the focus of each publication on its own audience with its needs and background knowledge.
\end{abstract}

Постановка проблеми. У сучасному медійному дискурсі найбільш поширені два жанри - виступи, які функціонально корелюють із промовами античних риторів, і новини, попередниками яких слугують оповіщення глашатаїв $[1$, с. 720$]$. Ці медійні жанри трансформувалися в результаті заміни безпосередньої комунікації голосом новими формами й способами спілкування. Відмінності між ними виявляються в композиції, вербальних засобах, способах залучення позамовного матеріалу, що демонструє зіставлення різдвяного вітання британської королеви Слизавети II, проголошеного у 2020 році, і його вербалізації в новинних текстах.
Міжжанрова трансформація в медійному дискурсі передбачає перекодування вербалізованого змісту, поданого в рамках одного жанру, засобами іншого. У нашому випадку це - трансформація змісту медійних виступів відомих осіб у тексти новин.

Сучасні лінгвісти потрактовують жанр як багатоетапне цілеспрямоване типове і впізнаване соціальне явище, що розвивається як тимчасово стабільна, але гнучка реакція на повторювані риторичні ситуації [2, с. 31]. Жанри є соціальними процесами, оскільки тексти завжди є інтерактивними практиками; цілеспрямованими, тому що 
текст узгоджується 3 метою учасників; багатоетапними, адже зазвичай потрібен більше ніж один хід, щоб досягти цілі комунікації [ibid]. Водночас жанрам притаманні обмеження в аспекті намірів співрозмовників, лексико-граматичних ресурсів дискурсивних ознак [3, с. 240], а гнучкість жанру спричинена вимогами, які накладаються постійно змінюваними соціально-культурними ситуаціями. Жанрова форма включає всі його матеріальні вияви, лінгвістичні й текстові елементи, що можуть різнитися від одного жанру до іншого: слова, речення, структуру, формат, композицію та інші візуальні елементи [4, с. 23]. Необхідність вивчення міжжанрових трансформацій, задіяних під час вербалізації змісту промови в новинному тексті, i виокремлення їх різновидів зумовлює актуальність статті.

Метою розвідки $є$ встановлення риторичних моделей, використаних журналістами під час передачі змісту різдвяного виступу королеви Слизавети II у 2020 році у трьох онлайн виданнях: британському, американському й канадському.

Для досягнення поставленої мети потрібно вирішити такі завдання: виокремити моделі текстопобудови різдвяного виступу Слизавети II [5] i новинних текстів; порівняти моделі для встановлення особливостей передачі змісту промови в британському [6], американському [7] і канадському [8] виданнях.

Об'сктом дослідження є різдвяне звернення Єлизавети II та новинні повідомлення про нього, а предметом вивчення - моделі трансформації публічного виступу в медійні тексти.

Виклад основного матеріалу. Публічний виступ як жанр - це усна промова політичного лідера або відомої особи задля висвітлення певної інформації та впливу на розум, почуття й волю слухача. У свою чергу, медійний виступ - промова політичного лідера або відомої особи, поширювана технічними засобами задля висвітлення певної інформації та впливу на розум, почуття й волю масового слухача.

Риторична структура публічного виступу включає шість частин: вступ, який формулює предмет і мету промови; нарацію, тобто виклад фактів і фонової інформації, потрібної для розуміння виступу; протиставлення, котре визначає спірні питання й перераховує аргументи, які ритор планує використовувати у виступі; докази; спростування аргументів опонента й висновок $[9$, с. 162].

Новинний текст як окремий інформаційний жанр характеризується стислим викладом ключової інформації щодо певної події, яка сталася нещодавно. Новинний текст має дати відповідь на запитання хто (щуо), щцо зробив/зробила, де, коли, як. При цьому його структура корелює 3 риторичною схемою побудови промови. Вступ співвідноситься із заголовком, основна функція якого - привернути увагу аудиторії, та 3 інтродуктивним абзацом [10, с. 173]. Риторична нарація співвідноситься з основною частиною статті, яка має дати відповідь на запитання хто (щуo), щзо зробив/зробила, де, коли, як. Риторичний етап доказів корелює з блоком коментарів, які цитують думки протилежних сторін.

Обидва тексти - публічний виступ i новинний текст $-\epsilon$ медійними, тому що поширюються технічними засобами й апелюють до масового адресата. Композиція виступу та мовне втілення поданих ідей зазнають змін унаслідок медіатизації, тобто процесу, під час якого ключові елементи соціальної або культурної активності набувають медійних форм [11, с. 48], у цьому випадку публічний виступ поєднується 3 практикою побудови новинних текстів.

Висвітлення медійних виступів у новинних текстах передбачає три процедури: фільтрування матеріалу, що подається в новинах, за рахунок приховування певної інформації або тлумачення певних явищ і реалій; пряме та непряме цитування; модифікація лінгвальних одиниць, представлених як окремими словами, так і конструкціями. Трансформації змісту промови можна вивчати із застосуванням когнітивно-риторичного підходу, який поєднує канони інвенції, тобто відбору теми, диспозиції, що охоплює тестову організацію ідей, та елокуції, пов'язаної з вербалізацією змісту [12, с. 48].

3 точки зору диспозиції різдвяне звернення королеви у 2020 році присвячене боротьбі ii народу 3 пандемією коронавірусу і включає вісім тем, лінеаризація яких підпорядкована авторській інтенції впливу на масову аудиторію [1, с. 719]: інтродуктивний блок, що виражає надію під час скрутних часів; релігійні святкування; волонтерство; вдячність медичним працівникам; похвала незнайомцям, котрі допомагали нужденним; ушанування меморіалу та подвигу Невідомого солдата; підтримка тих, що втратили родичів чи друзів, і заключний блок.

Промова королеви містить три ключові ідеї. По-перше, це світло, що приносить надію. В інтродуктивному абзаці світло представлене конструкціями turning on the lights, light brings hope та Jesus is 'the light of the world', у яких іменник light указує на забезпечення можливості. У блоці про релігійні святкування ідея світла втілена одиницями, що відображають надання фізичної можливості розрізняти об'єкти (festival of lights) і набуття предметами світла (fireworks lit up), тоді як надія відображена joyous moments of hope. У блоці про медпрацівників королева порівнює внесок Флоренс Найтінгейл і сучасних медпрацівників, 
де ідея світла представлена одиницями в минулому й теперішньому часі відповідно (shone a lamp of hope, shine that lamp), у яких іменник lamp, що називає пристрій для подачі світла, метафорично вказує на джерело надії. Допомога нужденним незнайомцями репрезентована метафоричними одиницями на позначення джерела світла, що приносить надію всім оточуючим hope in the new dawn, безпосередньо королеві my inner light. Заключний блок, присвячений біблійним мотивам, указує на зірку як джерело світла a star appeared in the sky, its light і Різдво як основу надії для віруючих the light of Christmas. По-друге, у промові Єлизавета II відображає своє захоплення вчинками людей у скрутний час: I have been inspired; continue to be inspired; people have risen magnificently; quiet, indomitable spirit. По-третє, королева висловлює вдячність як працівникам медичної сфери, так і волонтерам за допомогою конструкцій I say thank you; owe them a debt of gratitude [5].

Репрезентації ії ідей у медійних текстах різниться в трьох проаналізованих новинах, що зумовлено спрямованістю видання на власного читача та його потреби.

Представлення промови Слизавети II у британському виданні [6], яке має найбільшу міжнародну аудиторію і відоме позитивним ставленням до монархії, зорієнтовано на позиціонування королеви як турботливої та вдячної людини. У заголовку процитовано ідею 'You are not alone', яка імплікує підтримку, а підзаголовок указує на слова втіхи та заспокоєння: reassure anyone struggling without friends and family. Порядок подачі тем зі звернення королеви в основному блоці тексту зумовлений необхідністю підбадьорити людей під час пандемії: слова підтримки (a simple hug or a squeeze of the hand; there is hope in the new dawn); єднання людей у важкі часи (acts of kindness; "brought us closer"); схвалення вчинків волонтерів і пересічних людей (praised acts of kindness; has been "inspired" by people volunteering; I am so proud and moved; people have risen magnificently; quiet, indomitable spirit); опис релігійних святкувань (people of all faiths; highlighted Diwali celebrations), які є прикладом надії та єднання людей (an example of "joyous moments of hope and unity"); слова розради тим, хто втратив родичів або друзів (mourning the loss, you are not alone, assure you of my thoughts and prayers); вдячність (gave particular thanks) молоді та працівникам медичної сфери (to young people, to frontline workers), котрих вона порівнює 3 добрими самаритянами (good Samaritans) і Невідомим солдатом (the Unknown Warrior); апеляція за рахунок прямого цитування заключного блоку промови до самовідданості, любові й надії (the spirit of selflessness, love and above all, hope), які надає віруючим світло Різдва (the light of Christmas). Крім того, заключний блок новинного тексту містить особисту інформацію про королеву, ії сім'ю та їхні плани на свята.

Вербалізація змісту промови королеви в американському виданні [7] має подібності до британської новини. Заголовок виокремлює ідею, ідентичну британському виданню: 'you are not alone'. У підзаголовку вказано на схвалення монархом роботи медпрацівників (commended frontline workers) і зворушення незламним духом пересічних громадян (how "moved" she was by the "quiet, indomitable spirit”). В основному блоці статті відображено ієрархію тем згідно з роллю релігійного свята й звичними для віруючих практиками: неможливість повноцінно відзначати християнські релігійні свята (unable to celebrate); слова підбадьорення для тих, хто зазнав непоправних утрат, за допомогою прямого цитування (mourning the loss, a simple hug or a squeeze of the hand, assure you of my thoughts and prayers); нездатність відзначити свята представниками інших конфесій (those from other religious backgrounds, unable to celebrate); захоплення людьми, які допомагали нужденним (had been inspired by stories); вдячність медпрацівникам і науковцям (owed a "debt of gratitude" to those who worked in frontline services and in the scientific fields). Видання надає додаткову інформацію про звичне святкування Різдва королевою та ії сім'єю й у 2020 році та деталі про особистий досвід у їхній боротьбі з коронавірусом. Заключний блок новини містить пряме цитування заключної частини виступу монарха.

Канадське видання [8] виносить у заголовок ідею надії (message focuses on hope), що ідентично головному посилу промови, i називає минулий рік 'охопленим пандемією' (pandemic-stricken year), хоча сама Єлизавети II уникає апеляції до коронавірусу. Підзаголовок містить пряме цитування, яке вказує на позитивний момент важкого року зближення людей (brought us closer). Основний блок новинного тексту відзначається орієнтацією на вклад пересічних людей у боротьбу з вірусом та акцентує визнання королевою незламного духу ("indomitable" spirit) людей, що протистояли труднощам (rose to the challenges) під час скрутних часів ("difficult and unpredictable times"); словами підтримки тим, хто втратив близьких, за допомогою прямого цитування (mourning the loss, a simple hug or a squeeze of the hand, assure you of my thoughts and prayers); вставним блоком про ситуацію з коронавірусом у Сполученому королівстві; схваленням монархом діяльності волонтерів (celebrating the actions of those who have stepped up to provide help, inspired by stories of people volunteering), визнанням вкладу медпрацівників і молоді (highlighted the contributions of front-line 
workers and young people), котрих вона порівняла 3 добрим самаритянином (the Good Samaritan) i Невідомим солдатом (the Unknown Warrior); прямим цитуваннм заключного блоку промови; а також додаткоою інформацією про святкування Різдва королівською родиною.

Як бачимо, риторична побудова новинних повідомлень містить подібні та відмінні компоненти, що тлумачимо орієнтацією видання на свою цільову аудиторію. Британське й американське видання виносять у сильну позицію заголовок ідею підтримки монархом своїх підданих, тоді як канадське акцентує важливість надії в скрутні часи, тобто апелює до емоцій королеви та пересічних людей відповідно. Усі три тексти надають слова розради тим, хто пережив утрату рідних чи друзів, при чому за рахунок прямого цитування королеви, яке підсилює об'єктивність новини; відображають вдячність медпрацівникам; цитують заключну частину промови, присвячену ролі Різдва в житті вірян, що зумовлено призначенням щорічного звернення Слизавети II. Водночас існують певні відмінності у виборі тем. Лише американський текст указує на визнання ролі науковців, адже наука всіляко підтримується й розвивається в США; тільки канадське повідомлення акцентує на труднощах, які зазнали люди, апелюючи до емоцій реципієнтів.

Крім того, новинні тексти містять відмінності в представленні змісту промови, зумовлені фоновими знаннями читачів. Так, висловлюючи подяку робітникам медичної сфери, Слизавета II нагадала їм про меморіал Могила невідомого солдата як символ безкорисного служіння та самопожертви [12].

Трансформація змісту в британському виданні здійснюється за рахунок прямого цитування монарха. Указано значення пам'ятника для королеви та їі підданих.

Referring to the centenary of the Unknown Warrior's burial in Westminster Abbey, she said: "The Unknown Warrior was not exceptional, that's the point. He represents millions like him who, throughout our history, have put the lives of others above their own and will be doing so today.

"For me, this is a source of enduring hope in difficult and unpredictable times" [6].

У канадському виданні меморіал згадується в більш узагальненому вигляді. Подано його назву the Unknown Warrior і пояснено його значення за допомогою конструкції, синонімічної одиниці в промові Слизавети II (an unidentified British soldier from the First World War), а також репрезентовано розташування пам'ятника не лише за допомогою вказівки на собор (Westminster Abbey), а й місто (London), що може бути пояснено недостатніми знаннями аудиторії та прагненням журналіста заповнити прогалини в картині світу читачів.
The Queen in particular highlighted the contributions of front-line workers and young people, evoking the parable of the Good Samaritan, as well as the Unknown Warrior, an unidentified British soldier from the First World War whose tomb is at London's Westminster Abbey [8].

Що стосується американської новини про виступ британської королеви, то згадування зазначеного меморіалу взагалі там відсутнє.

Висновки. Аналіз моделей трансформації різдвяного звернення королеви в трьох новинних текстах онлайн-сайтів різних націй показав, що зміни в текстопобудові зумовлені спрямованістю видання на власного реципієнта, який різниться потребами й фоновими знаннями. Британське видання репрезентує Слизавету II турботливою про пересічних громадян у важкі часи і вдячною кожному підданому, вжило найбільше тем і випадків прямого цитування (15) для об’ єктивації іiї звернення. Американське видання зосередилося висловленні підтримки та вдячн на схваленні роботи професіоналів і волонтерів, ості монархом. Канадський новинний текст виносить у сильну позицію переживання читачів, їхній досвід під час пандемії, а також подає підтримку королеви та її схвалення діяльності медпрацівників і молоді.

Перспективи подальших розробок убачаємо у вивченні процесу медіатизації змісту промови в мовному, конструкційному, аспекті на елокутивному рівні.

\section{ЛІТЕРАТУРА}

1. Потапенко С.И. Когнитивная риторика эффекта: сопоставление масс-медийных жанров. Когнитивные исследования языка. Тамбов, 2015. Вып. XX : От когнитивной лингвистики к когнитивному терминоведению. C. 717-726.

2. Gruber H. Genres in political discourse: The case of the 'inaugural speech' of Austrian chancellors. Analyzing genres in political communication. Amsterdam : John Benjamins, 2013. P. 29-72.

3. Bhatia V. Professional written genres. The Routledge handbook of discourse analysis. London and New York : Routledge, 2014. P. 239-251.

4. Devitt A.J. Re-fusing form in genre studying. Genres in the Internet: Issues in the theory of genre. Amsterdam, Philadelphia : John Benjamins Publishing, 2009. 294 p.

5. The Christmas Broadcast 2020. URL: https:// www.royal.uk/christmas-broadcast-2020 (дата звернення: 10.08.2021).

6. Queen's Christmas speech: 'You are not alone'. URL: https://www.bbc.com/news/uk-55447011 (дата звернення: 10.08.2021). 
7. Queen Elizabeth says 'you are not alone' in annual Christmas speech. URL: https:// edition.cnn.com/2020/12/25/europe/queenelizabeth-annual-christmas-speech-intl-gbr/ index.html (дата звернення: 10.08.2021).

8. Queen Elizabeth's Christmas message focuses on hope at close of pandemic-stricken year. URL: https://www.cbc.ca/news/world/queen-elizabethchristmas-message-2020-1.5854398 (дата звернення: 10.08.2021).

9. Leith S. You Talkin' To Me?: Rhetoric from Aristotle to Obama. London : Profile Books, 2011.287 p.

10. Дем'янова А.О. Редакторське опрацювання заголовків інтернет-новин. Наукові записки Інституту журналістики. 2010. Т. 41. C. $172-176$.

11. Hjarvard S. From Bricks to Bytes: The Mediatization of a Global Toy Industry. European Culture and the Media. Bristol : Intellect Books, 2004. P. 43-63.

12. Lauer J.M.Invention in Rhetoric and Composition. Indiana : Parlor Press, 2004. 240 p.

\section{REFERENCES}

1. Potapenko, S.I.(2015). Cognitiverhetoric of effect: correlation of mass-media genres [Kognitivnaia ritorika effekta: sopostavlenie mass-mediinyh zhanrov]. Kognitivnyie issledovaniia iazyka, vol. XX. Ot kognitivnoi lingvistiki $\mathrm{k}$ kognitivnomu terminovedeniiu, pp. 717-726.

2. Gruber, H. (2013). Genres in political discourse: The case of the 'inaugural speech' of Austrian chancellors. Analyzing genres in political communication. Amsterdam: John Benjamins, pp. 29-72.

3. Bhatia, V. (2014). Professional written genres. The Routledge handbook of discourse analysis. London and New York : Routledge, pp. 239-251.

4. Devitt, A. J. (2009). Re-fusing form in genre studying. Genres in the Internet: Issues in the theory of genre. Amsterdam, Philadelphia : John Benjamins Publishing.

5. The Christmas Broadcast 2020. URL: https:// www.royal.uk/christmas-broadcast-2020.

6. Queen's Christmas speech: 'You are not alone'. URL: https://www.bbc.com/news/uk-55447011.

7. Queen Elizabeth says 'you are not alone' in annual Christmas speech. URL: https://edition.cnn.com/ 2020/12/25/europe/queen-elizabeth-annualchristmas-speech-intl-gbr/index.html.

8. Queen Elizabeth's Christmas message focuses on hope at close of pandemic-stricken year. URL: https://www.cbc.ca/news/world/queen-elizabethchristmas-message-2020-1.5854398.

9. Leith, S. (2011). You Talkin' To Me?: Rhetoric from Aristotle to Obama. London: Profile Books.

10. Demianova, A. O. (2010). Editor's processing of internet-news headlines [Redaktorske opratsiuvannia zagolovkiv internet-novyn]. Naukovi zapysky Instytutu zhurnalistyky, vol. 41, zovtengruden, pp. 172-176.

11. Hjarvard, S. (2004). From Bricks to Bytes: The Mediatization of a Global Toy Industry. European Culture and the Media. Bristol : Intellect Books, pp. 43-63.

12. Lauer, J. M. (2004). Invention in Rhetoric and Composition. Indiana : Parlor Press. 